Халеп Ю. М., к.е.н. Інститут сільськогосподарської мікробіології та агропромислового виробництва Національної академії аграрних наук України м. Чернігів, Украӥна

Шаповалюк М. В., к.е.н. Відокремлений підрозділ Національного університету біоресурсів і природокористування України "Ніжинський агротехнічний інститут» м. Ніжин, Чернігівська область, Украӥна DOI: https://doi.org/10.30525/978-9934-26-028-5-41

\title{
ЕКОНОМГЧНІ ПЕРЕДУМОВИ РОЗВИТКУ ОРГАНІЧНОГО ЗЕМЛЕРОБСТВА В УМОВАХ ПОЛІССЯ УКРАЇНИ
}

На сьогодні органічне виробництво сільськогосподарської продукції в Україні ще не набуло належного поширення, особливо щодо забезпечення власного населення в доступних органічних продуктах харчування. Адже на даний час органічні товаровиробники під тиском кон'юнктурних та економічних факторів (низькі ціни на органічну продукцію, недостатній платоспроможний попит українців тощо) здебільшого віддають перевагу вузькій спеціалізації на експортоорієнтованих та нішевих видах продукції, що підтверджується висновками й інших дослідників [1]. За таких обставин при розробленні моделей органічних господарств, зокрема схем сівозмін, слід дотримуватися як загальноприйнятих засад біологічного й агрономічно-організаційного спектру, так i першочергових державницьких пріоритетів, зокрема: в умовах обмеженої кількості грунтів, придатних для органічного виробництва, при виборі виробничих напрямів перевагу слід надавати культурам, призначеним на харчові цілі; необхідність забезпечення власного населення в доступних органічних продуктах харчування тощо. У той же час, реалізація зазначених пріоритетів має бути 
забезпечена належними економічними передумовами мотивації потенційних органічних товаровиробників, передусім шляхом фінансової підтримки.

Оскільки засадним принципом органічного землеробства $\epsilon$, насамперед, забезпечення екологічної сталості агроценозів, то при розробленні органічних виробничих моделей слід керуватися, передусім, цим критерієм. I вже на цій основі необхідно створювати умови забезпечення економічної мотивації досягнення вищевикладеного.

3 урахуванням зазначеного в процесі попередніх досліджень нами було розроблено низку типових моделей сівозмін органічного виробництва сільськогосподарської продукції для господарств зони Полісся України [2-4]. У той же час детальний аналіз економічних передумов не входив в задачу згаданих досліджень. Тому в даній публікації основна увага зосереджена саме на цих аспектах на прикладі однієї із розроблених типових моделей сівозмін рослинницького виробничого спрямування.

Схема сівозміни має наступний вигляд: 1) конюшина на насіння; 2) озиме жито, люпин на сидерат; 3) просо, редька на сидерат; 4) горох; 5) озима пшениця, редька на сидерат; 6) картопля, озиме жито на сидерат; 7) яра пшениця 3 підсівом конюшини.

Розроблена система удобрення побудована на внутрішньогосподарських ресурсах (побічна продукція, сидерати, насичення сівозміни зернобобовими і бобовими культурами) та застосуванні біопрепаратів - вона $є$ базовою і може бути доповнена надходженнями органічних добрив із місцевих джерел.

Прогнозні розрахунки основних показників екологічної ефективності по даній моделі показали, що за рахунок широкого застосування та активізації біологічних чинників удобрювального процесу та відповідного добору вирощуваних основних та проміжних сільськогосподарських культур з часом створюються можливості для досягнення прийнятного рівня екологічної сталості представленого агроценозу. 
При цьому розроблена система удобрення теоретично дозволяє сформувати такий розмір удобрювального потенціалу, який $\epsilon$ достатнім для досягнення прийнятного, за умов органічного виробництва, рівня продуктивності сівозміни. Так, згідно прогнозних розрахунків, вихід зернових одиниць із розрахунку на 1 га сівозмінної площі досягає 3,07 т.

Основні показники економічної ефективності досліджуваної сівозміни за цінової ситуації 2017-2019 pр. наведені в таблиці 1.

Таблиця 1

\section{Прогнозні розрахунки основних показників} економічної ефективності досліджуваної моделі (в середньому за рік після освосння сівозміни)

\begin{tabular}{|l|c|c|c|c|}
\hline \multirow{2}{*}{$\begin{array}{c}\text { С.-г. } \\
\text { культура }\end{array}$} & \multicolumn{2}{|c|}{$\begin{array}{c}\text { За середніх фактичних } \\
\text { цін реалізації }\end{array}$} & \multicolumn{2}{|c|}{$\begin{array}{c}\text { За цін реалізації } \\
\text { зорганічною» } \\
\text { надбавкою }\end{array}$} \\
\cline { 2 - 5 } & $\begin{array}{c}\text { прибуток } \\
\text { на 1 га, } \\
\text { грн. }\end{array}$ & $\begin{array}{c}\text { Рента- } \\
\text { бельність, } \\
\text { \% }\end{array}$ & $\begin{array}{c}\text { прибуток } \\
\text { на 1 га, грн. }\end{array}$ & $\begin{array}{c}\text { Рента- } \\
\text { бельність, } \\
\text { \% }\end{array}$ \\
\hline Насіння конюшини & 381 & 5,4 & 2631 & 37,0 \\
\hline Озиме жито & -1211 & $-12,8$ & 1256 & 13,3 \\
\hline Просо & 1410 & 13,0 & 5076 & 47,0 \\
\hline Горох & 2817 & 20,1 & 7862 & 56,2 \\
\hline Озима пшениця & 1171 & 10,9 & 4747 & 44,2 \\
\hline Картопля & 20755 & 39,7 & 42671 & 81,6 \\
\hline Яра пшениця & -647 & $-6,3$ & 2236 & 21,8 \\
\hline По сівозміні & 3525 & 21,5 & 9497 & 58,0 \\
\hline
\end{tabular}

Джерело: розраховано авторами за результатами власних досліджень

Розрахунки (табл. 1) проведено за двома варіантами цін реалізації: за фактичними цінами, що склалися на ринку України (з домінуванням продукції, вирощеної за традиційними технологіями) та за цінами з урахуванням «органічної» надбавки на рівні 30\%, як усередненого показника сформованих ринків подібної органічної продукції [5].

Із отриманих даних (табл. 1) видно, що «звичайні» ціни не забезпечують досягнення необхідного рівня прибутковості 
виробництва органічної продукції. Хоча в цілому модель $\epsilon$ рентабельною, але за рівнем економічної ефективності вона не в змозі конкурувати 3 інтенсивними технологіями, а більшість культур є збитковими або ж низькодохідними.

За умови введення «органічних» цін на продукцію більшість вирощуваних культур досягають прийнятного рівня рентабельності. Але застосування усередненої надбавки не забезпечує достатнього рівня конкурентоспроможності жита та ярої пшениці. Тому в якості досконалішого механізму ціноутворення на органічну продукцію рослинництва можна запропонувати методику, розроблену науковцями Національного наукового центру «Інститут аграрної економіки», якою передбачено наступні чинники формування «органічної» надбавки, в тому числі, з урахуванням місцевих умов: коефіцієнт продуктивності (відношення середньої врожайності окремої культури за традиційної технології до їі середньої врожайності за органічної технологіі); коефіцієнт ризику втрати врожаю; коефіцієнт сівозміни (врахування продуктивності сівозміни в цілому); коефіцієнт втрат при зберіганні [6]. У той же час, на нашу думку, механічне застосування зазначених коефіцієнтів несе в собі ризик недостатньої мотивації для підвищення продуктивності виробництва та збереженості продукції. За авторським баченням, застосування подібного механізму ціноутворення на органічну продукцію має супроводжуватися і відповідними зобов'язаннями з боку товаровиробника.

Тому на початковому етапі розвитку i поширення такого напряму органічного виробництва, орієнтованого на забезпечення власного населення в доступних органічних продуктах харчування, він може реалізуватися через фінансовані державою або органами місцевого самоврядування пілотні проєкти 3 обумовленим економічним механізмом забезпечення інтересів товаровиробника та його зобов'язаннями щодо досягнення належного рівня продуктивності виробництва тощо. 


\section{Література:}

1. Bondar V. Organic grain production market of Ukraine: prospects and trends. Baltic Journal of Economic Studies. 2016. Vol. 2, no. 3, pp. 17-22. DOI: https://doi.org/10.30525/2256-0742/2016-2-3-17-22.

2. Оцінка еколого-економічної ефективності моделей органічного виробництва сільськогосподарської продукції (методичні рекомендації) / Ю.М. Халеп, А.М. Москаленко, В.В. Волкогон, Ю.Г. Смець, А.Ю. Халеп. Чернігів, 2015. $32 \mathrm{c}$.

3. Khalep Yu., Moskalenko A. Ecological and economic aspects of the efficiency of Polissia organic plant models. Agricultural and Resource Economics. 2020. Vol. 6. No. 4. Pp. 5-19. URL: https://are-journal.com.

4. Халеп Ю.М., Москаленко А.М., Волкогон В.В. Оцінка екологоекономічної ефективності систем удобрення в сівозмінах органічного виробництва Полісся (науково-методичні рекомендації). Чернігів, 2020. 48 с.

5. De Leijster V., Verburg R.W., Santos M.J., Wassen M.J., Martínez-Mena M., de Vente J., Verweij P.A. (2020) Almond farm profitability under agroecological management in south-eastern Spain: Accounting for externalities and opportunity costs. Agricultural System. No. 183. DOI: https://doi.org/10.1016/j.agsy.2020.102878.

6. Методичні рекомендації з ціноутворення на органічну продукцію / [Лупенко Ю.О., Месель-Веселяк В.Я., Саблук П.Т. та ін.] ; за ред. Ю.О. Лупенка, В.Я. Месель-Веселяка. Київ : ННЦ ІАЕ, 2013. 88 с. 